University of Nebraska - Lincoln

DigitalCommons@University of Nebraska - Lincoln

1995

\title{
Differences in Pup Birth Weight, Pup Variability Within Litters, and Dam Weight of Mice Selected for Alternative Criteria to Increase Litter Size
}

\author{
M. A. J/ Van Engelen \\ Agricultural University Wageningen, Marijkeweg 40, Wageningen, The Netherlands \\ Merlyn K. Nielsen \\ University of Nebraska-Lincoln, mnielsen1@unl.edu \\ E. L. de A. Ribeiro \\ Universidade Estadual de Londrina, Brazil
}

Follow this and additional works at: https://digitalcommons.unl.edu/animalscifacpub

Part of the Animal Sciences Commons

Van Engelen, M. A. J/; Nielsen, Merlyn K.; and de A. Ribeiro, E. L., "Differences in Pup Birth Weight, Pup Variability Within Litters, and Dam Weight of Mice Selected for Alternative Criteria to Increase Litter Size" (1995). Faculty Papers and Publications in Animal Science. 492.

https://digitalcommons.unl.edu/animalscifacpub/492

This Article is brought to you for free and open access by the Animal Science Department at DigitalCommons@University of Nebraska - Lincoln. It has been accepted for inclusion in Faculty Papers and Publications in Animal Science by an authorized administrator of DigitalCommons@University of Nebraska - Lincoln. 


\title{
Differences in Pup Birth Weight, Pup Variability Within Litters, and Dam Weight of Mice Selected for Alternative Criteria to Increase Litter Size ${ }^{1}$
}

\author{
M.A.J. van Engelen', M. K. Nielsen ${ }^{3}$, and E. L. de A. Ribeiro ${ }^{4}$ \\ University of Nebraska-Lincoln, Lincoln 68583-0908
}

\begin{abstract}
Selection for litter size had been practiced for 21 generations and relaxed selection for 13 generations in mice. Three replicates were used with four selection criteria: index of components (ovulation rate and ova success), uterine capacity, litter size, and an unselected control. Especially with selection for litter size and the index relative to the control, number of pups born had increased, and differences also occurred in mating weight. Dams of the three replicates and their litters were used to evaluate the effects of accumulated selection on pup birth weight, variability in weight of littermates, and dam's weight at mating and after littering. Total number born, number born alive, number of males, and number of females were also recorded and studied. Mean pup birth weight did not differ among the criteria; however, variability among littermates in
\end{abstract}

pup weight tended to differ among criteria of selection. Regressions for pup weight and within-litter standard deviation of pup weight on number born were small and negative but significant $(P<.001)$. The distribution of pup weight within litter was normal for $77.2 \%$ of the litters, with no differences among the criteria. The difference between weight of male and weight of female pups was significant $(P<.001)$; overall males were $2.5 \%$ heavier than females. There was a difference $(P<.02)$ among criteria in mating weight and littering weight; however, the maternal weight gain between mating and littering was not different among criteria. Number born differed $(P<.003)$ among the criteria, but there was no significant difference among criteria in numbers of males and females. Selection for larger litters did not have a large effect on the mean or variability within litter for pup birth weight.

Key Words: Mice, Litter Size, Pup Weight, Dam Weight, Variability, Selection

J. Anim. Sci. 1995. 73:1948-1953

\section{Introduction}

Kirby and Nielsen (1993) reported responses in mice as large as four pups through 21 generations of replicated selection to increase number born using alternative criteria and six subsequent generations of relaxed selection. Clutter et al. (1994) have reported differences for uterine capacity in these same lines as large as $23 \%$, measured in unilaterally ovariectomized females.

\footnotetext{
${ }^{1}$ Published as paper no. 10516, Journal Series, Agric. Res. Div., Univ, of Nebraska, Lincoln 68583-0908.

${ }^{2}$ Dept. of Anim. Breed., Agricultural University Wageningen, Marijkeweg 40, Wageningen, The Netherlands.

${ }^{3}$ To whom correspondence should be addressed: A218 Animal Science.

${ }^{4}$ Supported by Conselho Nacional de Desenvolvimento Cientifico e Tecnologico (CNPq) and Universidade Estadual de Londrina, Brazil.

Received May 31, 1994.

Accepted March 29, 1995.
}

Body mass of females has also increased, but proportionately less than litter size and the component traits from the same selection (Kirby and Nielsen, 1993). Pup birth weight may be expected to decline and its variability within litter to increase due to uterine crowding and competition for nutrients with increased litter size. Also, any possible relationship between pup variability in birth weight and size of litter may be different in lines resulting from different selection criteria.

The primary objectives of this study were to determine whether the different selection criteria in the experiment described by Kirby and Nielsen (1993) produced differences in average pup weight and variability among littermates for birth weight, and whether the relationships between litter size and mean pup weight and variability of pup weight are the same in the populations produced by each criterion of selection, independent of the weight of the dam. Secondary objectives were to assess selection's effect on maternal gain during pregnancy and to measure differences in number born and dam weight after 13 generations of relaxed selection. 


\section{Materials and Methods}

Population Background. Mice from 12 selection lines, derived from a CF1 base, were used. Four criteria were used for selection that were replicated three times in independent lines. Clutter et al. (1990) and Gion et al. (1990) described the selection criteria, population sizes, and general selection procedures. Brief descriptions of the criteria are as follows: IX = litters were selected on an index of components of litter size $(1.21 \times$ ovulation rate $+9.05 \times$ ova success, where ovulation rate was the number of corpora lutea and ova success was the ratio of number born:number of corpora lutea), UT = litters were selected on number born to unilaterally ovariectomized females, LS = litters were selected on number born to unaltered females, and LC = no selection.

Estimations of selection responses after 21 generations of selection were reported by Kirby and Nielsen (1993). Selection ceased after 21 generations, and Generations 22 through 35 were maintained with relaxed selection and matings assigned to minimize inbreeding.

Relaxed Selection. Thirty-two litters per line supplied breeders each generation from Generations 22 though 35. Litters were standardized to eight, ideally five females and three males, at birth. One male and two females, when available, were randomly assigned as breeders from each litter, usually resulting in 64 females mated for each line in each generation. The generation interval was $15 \mathrm{wk}$, and the replicates were separated by $5 \mathrm{wk}$. Animals were mated at approximately $12 \mathrm{wk}$, and performance was measured at first parity only. Animals in littering cages had access to a rodent-block diet containing $20 \% \mathrm{CP}, 10 \%$ fat, and $2 \%$ crude fiber. Animals in growing and breeding cages had access to a rodent-block diet containing $24 \% \mathrm{CP}, 4 \%$ fat and $4.5 \%$ crude fiber. Animals were given ad libitum access to diets and water. Temperature in the laboratory was kept at $23^{\circ} \mathrm{C}$ with 12 -h dark: 12 -h light cycles. Females in the UT lines were not unilaterally ovariectomized and ovulation rate was not measured in the IX lines; this is in contrast to the procedures followed during the selection phase (Generations 0 through 21).

Data Collected. Dams from Replicate 3 Generation 34, Replicate 1 Generation 35, and Replicate 2 Generation 35 were used for data collection. Although we would have preferred to measure all animals from the same generation, we were limited to a fixed time interval that did not include Replicates 1 and 2 of Generation 34 or Replicate 3 of Generation 35 . Because there were no changes during the generations of relaxed selection, we expected the same variation between replicates across the two generations as within a generation. Number of pups born, number of pups born alive, and numbers of males and females were counted. Dam weight at the start of the mating period, her littering weight after parturition, and birth weight of each pup were measured. Maternal gain was the difference between dam littering weight and mating weight. The total data set included 726 dams and 9,425 pups. Dams were checked for littering twice a day, early in the morning and late in the afternoon.

Statistical Analysis. All analyses were conducted using SAS (1992). Four models were used to evaluate sources of variability. The general model [1] included the effect of replicate, selection criterion, and replicate $\times$ criterion interaction. Another model [2] expanded model [1] to include the continuous effect of number born plus the interactions of criterion $\times$ number born and replicate $\times$ criterion $\times$ number born. A third model [3] had the effects in model [1] plus that of dam (replicate-criterion), sex of pup, and the interactions of sex $\times$ criterion, and sex $\times$ replicate $\times$ criterion. Finally, a fourth model [4] expanded model [1] to include the continuous effects of mating weight and number born plus the interactions of criterion $x$ mating weight, replicate $\times$ criterion $\times$ mating weight, criterion $\times$ number born, and replicate $x$ criterion $\times$ number born.

Analyses with models [1], [2], and [4] were fitted using the GLM procedure. Due to the size of the model, analyses using model [3] were done using the ANOVA procedure. To carry out the computations, all effects in the models were fixed. For tests of significance, replicate plus all interactions with replicate were assumed random. The design was quite balanced, so using calculation procedures for fixed vs mixed models had little effect on the analyses of variance. Differences created by the selection criteria were tested with the replicate $x$ criterion interaction as the error term. Orthogonal contrasts of the criterion means were used to further explain the nature of the criterion differences. These contrasts were as follows: Contrast 1, general effect of selection $=(\mathrm{IX}+\mathrm{UT}+$ LS) $/ 3$ vs LC, Contrast 2 , selection for litter size vs selection for uterine capacity $=(\mathrm{IX}+\mathrm{LS}) / 2$ vs UT, and Contrast 3, index vs "regular" selection $=$ IX vs LS.

Dependent variables for analysis with model [1] were average pup weight in the litter, average live pup weight in the litter, standard deviation of pup weight in the litter; mating weight, littering weight, and maternal gain of the dams; total number born, number born alive, number of females, and number of males born. In addition, the standard deviations within a line for average pup weight, total number born, and mating weight were analyzed with model [1].

If uterine environment did not change relative to number of fetuses, larger litters might have smaller and more variable pups. Also, a larger number of fetuses may cause more maternal gain, or a dam with larger growth during pregnancy may have more fetuses that survive. Thus, average pup weight in a litter, standard deviation of pup weight in a litter, and 
maternal gain were also analyzed with model [2]. Possible selection effects on female and male pup weights were evaluated with model [3]; the sex $x$ criterion interaction was tested with sex $x$ replicate $x$ criterion. Between dams having an equal number born, larger dams might be expected to have larger pups. Thus, individual pup weight was evaluated with model [4].

Least squares means were calculated for models [1] and [3], and least squares means and solutions were calculated for models [2] and [4]. Interaction of continuous effects and selection criteria were tested, and where nonsignificant, the interaction was dropped from the model. If the interaction was significant, the continuous effect was fitted as a nested regression within each selection criterion.

To determine distributional properties of pup birth weights within a litter, skewness and kurtosis statistics were calculated for each dam and evaluated with model [1]. Tests for normality were done using the method of Shapiro and Wilk (1965) in SAS (1992). Litters were categorized as non-normal by two criterion levels, when the probability of the test was less than .1 or less than .05. Differences between selection criteria, following the contrasts shown above, for normal vs non-normal distributions were evaluated within replicate by chi-square, and then pooled across replicates and tested with a standard normal distribution (Snedecor and Cochran, 1967).

\section{Results and Discussion}

Pup Weight. Mean pup weight did not differ significantly among the selection criteria (Table 1 ). Mean weight of live pups also did not differ among criteria. The regression of average pup weight on number born in the litter was small and negative $(-.027 \pm .001 \mathrm{~g} / \mathrm{pup}, P<.001)$. Although significant in magnitude, an increase in number born did not have a large unfavorable effect on pup weight. For example, an increase of eight pups in number born for LC ( $8 /$
$10.72=75 \%$ of the mean) would reduce average pup weight by only $.216 \mathrm{~g}(.216 / 1.55=14 \%$ of the mean $)$. When dam weight was included in the model, criterion differences for pup weight were even smaller. The regression of average pup weight on mating weight was significant $(.011 \pm .002 \mathrm{~g}$ of pup/g of dam, $P<$ $.001)$. Bakker et al. (1978) found no changes in body weights of pups after selection for larger litters, although litter size at birth changed substantially.

The average difference between male and female littermates was $.045 \mathrm{~g}(2.5 \%)$; however, the sex $\times$ criterion interaction (model [3]) was significant $(P<$ .02). The difference in birth weight between males and females was much larger in IX than the other selection criteria. The difference in weight between males and females evidently occurs very early in development, because the difference was already detected at birth.

Standard deviations. The standard deviation of pup weight tended to differ among criteria $(P<.1$, Table 2 ). Criterion means for standard deviation of live pup weight followed the same pattern. Differences among criteria in standard deviations also existed for mating weight and number of pups born. For the standard deviation of mating weight, contrast IX, LS, UT vs LC was highly significant $(P<.01)$. Contrast $\mathrm{IX}, \mathrm{LS}$ vs UT was highly significant $(P<.01)$ for standard deviation of number of pups born. These results match with the results for mating weight and number born, because those means were also different between the criteria. For mating weight, the increase in the mean with selection has created a little more variability than would be expected from just scaling; the CV was 8.4 to $8.8 \%$ in IX, LS, and UT vs $7.8 \%$ in LC. The opposite occurred for number born; the CV in LC was highest at $26 \%$, and the selection criteria were lower at 20 to $23 \%$.

The interaction of criterion and number born was significant for standard deviation of pup weight. Therefore, number born and criterion $x$ number born in model [2] were replaced by the regression on number born for each criterion. The regressions were

Table 1. Selection criterion least squares means for pup weight and significance levels of contrasts

\begin{tabular}{|c|c|c|c|c|c|c|c|}
\hline Characteristic & IX & LS & UT & LC & 1 & 2 & 3 \\
\hline Pup wt, $g^{c}$ & $\begin{array}{r}1.53 \\
\pm \quad .03\end{array}$ & $\begin{array}{r}1.50 \\
+\quad .03\end{array}$ & $\begin{array}{r}1.54 \\
\pm \quad .03\end{array}$ & $\begin{array}{r}1.55 \\
\pm \quad .03\end{array}$ & $N^{d}$ & NS & NS \\
\hline Male pup wt, $\mathrm{g}^{\mathrm{c}}$ & $\begin{array}{r}1.54 \\
\pm .02\end{array}$ & $\begin{array}{r}1.50 \\
\pm .02\end{array}$ & $\begin{array}{r}1.55 \\
\pm \quad .02\end{array}$ & $\begin{array}{r}1.54 \\
\pm \quad .03\end{array}$ & NS & NS & NS \\
\hline
\end{tabular}

a IX $=$ index, $\mathrm{LS}=$ litter size, UT $=$ uterine capacity, and $\mathrm{LC}=$ control.

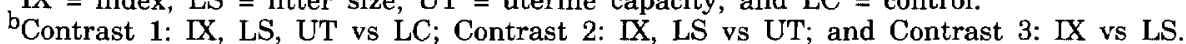

${ }^{\mathrm{c}}$ Model $=$ replicate + criterion + replicate $\times$ criterion .

$\mathrm{d}_{\mathrm{NS}}=$ not statistically significant. 
Table 2. Selection criterion least squares means of standard deviations within dams and across dams for weights and number born and significance levels of contrasts

\begin{tabular}{|c|c|c|c|c|c|c|c|}
\hline \multirow[b]{2}{*}{ Characteristic } & \multicolumn{4}{|c|}{ Criterion $^{\mathrm{a}}$ mean $\pm \mathrm{SE}$} & \multicolumn{3}{|c|}{ Significance level of contrast ${ }^{\mathrm{b}}$} \\
\hline & IX & LS & UT & LC & 1 & 2 & 3 \\
\hline $\begin{array}{l}\text { Within dams } \\
\text { SD pup wt, } \mathrm{g}^{\mathrm{c}}\end{array}$ & $\begin{array}{r}.104 \\
\pm .005\end{array}$ & $\begin{array}{r}.094 \\
\pm .005\end{array}$ & $\begin{array}{r}.089 \\
\pm .005\end{array}$ & $\begin{array}{r}.087 \\
\pm .005\end{array}$ & $\mathrm{NS}^{\mathrm{e}}$ & NS & NS \\
\hline $\mathrm{SD}$ pup wt, $\mathrm{g}^{\mathrm{d}}$ & $\begin{array}{r}.105 \\
\pm .005\end{array}$ & $\begin{array}{r}.095 \\
\pm .005\end{array}$ & $\begin{array}{r}.088 \\
\pm \quad .005\end{array}$ & $\begin{array}{r}.085 \\
\pm .005\end{array}$ & NS & .10 & NS \\
\hline $\begin{array}{l}\text { Across dams } \\
\text { SD no. born }\end{array}$ & $\begin{array}{r}3.13 \\
\pm .17\end{array}$ & $\begin{array}{r}3.38 \\
\pm .17\end{array}$ & $\begin{array}{r}2.49 \\
\pm .17\end{array}$ & $\begin{array}{r}2.83 \\
\pm .17\end{array}$ & NS & .01 & NS \\
\hline SD mating wt, $g^{c}$ & $\begin{array}{r}2.36 \\
\pm .09\end{array}$ & $\begin{array}{r}2.47 \\
\pm .09\end{array}$ & $\begin{array}{r}2.23 \\
\pm .09\end{array}$ & $\begin{array}{r}1.91 \\
\pm .09\end{array}$ & .01 & NS & NS \\
\hline $\mathrm{SD}$ pup wt, $\mathrm{g}^{\mathrm{c}}$ & $\begin{array}{r}.110 \\
+.011\end{array}$ & $\begin{array}{r}.123 \\
\pm .011\end{array}$ & $\begin{array}{r}.113 \\
\pm .011\end{array}$ & $\begin{array}{r}.132 \\
\pm .011\end{array}$ & NS & NS & NS \\
\hline
\end{tabular}

${ }^{\mathrm{a}} \mathrm{IX}=$ index, LS = litter size, UT = uterine capacity, and LC = control.

${ }^{b}$ Contrast 1: IX, LS, UT vs LC; Contrast 2: IX, LS vs UT; and Contrast 3: IX vs LS.

$\mathrm{c}_{\text {Model }}=$ replicate + criterion + replicate $\times$ criterion .

${ }^{\mathrm{d}}$ Model $=$ replicate + criterion + replicate $\times$ criterion + number born (criterion) as a covariate.

${ }^{\mathrm{e}} \mathrm{NS}=$ not statistically significant.

significantly different from zero for only the UT $(-.006$ $\pm .002 \mathrm{~g} / \mathrm{pup}, P<.001)$ and LC $(-.005 \pm .002 \mathrm{~g} / \mathrm{pup}, P$ $<.002)$; these were the criteria with less variability in their litters. Contrast IX, LS vs UT was significant ( $P$ $<.10$ ) for standard deviation of pup weight when adjusted for number born.

Ignoring the need to fit unique regressions, the overall regression for standard deviation of pup weight on number born was slightly negative, $-.001 \pm .0005 \mathrm{~g} /$ pup $(P<.03)$.

Distribution of Pup Weight in Litter. Whether categorizing litters at either the .1 or .05 probability levels for non-normality, the percentage of normal distributions of birth weight in the litter was not different among the selection criteria (Table 3 ). At the .1 level of probability, the LC had the highest overall percentage, $81.4 \%$, and the LS had the lowest overall percentage, $73.2 \%$. The overall average was $77.2 \%$ normal distribution. Skewness and kurtosis statistics were not different among the criteria.

Selection did not significantly influence the distribution of birth weight of littermates, although the percentage of normally distributed litters was highest in the control. This may be expected, if we assume body weights are normally distributed within litters in random mating populations. The values for skewness were negative; thus, the distributions were shifted a little to higher values. Also, there is a biological limit for very small pups, and thus it would seem unreasonable to expect distributions that are skewed

Table 3. Distributional statistics and proportions of distributions of pup weight in a litter that were normal by selection criteria

\begin{tabular}{|c|c|c|c|c|c|c|c|}
\hline \multirow[b]{2}{*}{ Statistics } & \multicolumn{4}{|c|}{ Criterion $^{\mathrm{a}}$ mean $\pm \mathrm{SE}$} & \multicolumn{3}{|c|}{ Significance level of contrast ${ }^{b}$} \\
\hline & IX & LS & UT & LC & 1 & 2 & 3 \\
\hline \multirow{4}{*}{$\begin{array}{l}\text { Skewness } \\
\text { Kurtosis }\end{array}$} & $-.42 \pm .06$ & $-.52 \pm .06$ & $-.42 \pm .06$ & $-.30 \pm .06$ & .06 & NS & NS \\
\hline & $.46 \pm .17$ & $.82 \pm .18$ & $.74 \pm .17$ & $.37 \pm .17$ & $\mathrm{NS}^{\mathrm{e}}$ & NS & NS \\
\hline & \multicolumn{4}{|c|}{ Criterion } & \multicolumn{3}{|c|}{ Significance level of contrast } \\
\hline & IX & LS & UT & LC & 1 & 2 & 3 \\
\hline \multicolumn{8}{|c|}{$\begin{array}{l}\text { Normally distributed litter, } \\
\% \text { cd }\end{array}$} \\
\hline Criterion .1 & 77.4 & 73.2 & 77.5 & 81.4 & NS & NS & NS \\
\hline Criterion .05 & 84.1 & 80.1 & 85.0 & 88.5 & NS & NS & NS \\
\hline \multicolumn{8}{|c|}{ 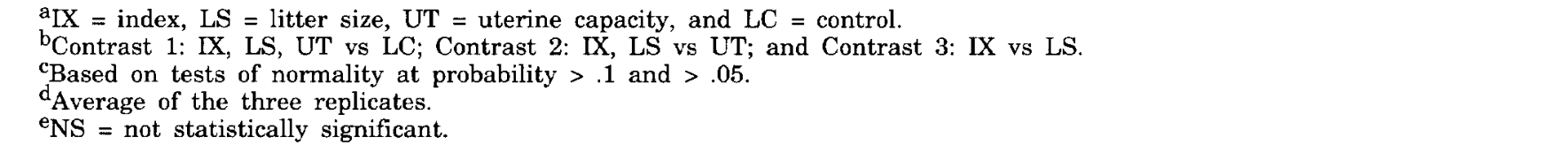 } \\
\hline
\end{tabular}


Table 4. Selection criterion least squares means for weights and gain of dams and significance levels of contrasts

\begin{tabular}{|c|c|c|c|c|c|c|c|}
\hline \multirow[b]{2}{*}{ Characteristic } & \multicolumn{4}{|c|}{ Criterion $^{\mathrm{a}}$ mean $\pm \mathrm{SE}$} & \multicolumn{3}{|c|}{ Significance level of contrast ${ }^{\mathrm{b}}$} \\
\hline & IX & LS & UT & LC & 1 & 2 & 3 \\
\hline Mating wt, $\mathrm{g}^{\mathrm{c}}$ & $\begin{array}{r}28.08 \\
\pm \quad .66\end{array}$ & $\begin{array}{r}28.19 \\
\pm \quad .67\end{array}$ & $\begin{array}{r}25.84 \\
\pm \quad .65\end{array}$ & $\begin{array}{r}24.64 \\
\pm \quad .65\end{array}$ & .01 & .03 & NS \\
\hline Littering $w t, g^{c}$ & $\begin{array}{r}38.04 \\
\pm \quad .93\end{array}$ & $\begin{array}{r}38.67 \\
\pm \quad .94\end{array}$ & $\begin{array}{r}35.38 \\
\pm \quad .91\end{array}$ & $\begin{array}{r}34.11 \\
\pm \quad .91\end{array}$ & .02 & .04 & NS \\
\hline Gain, $g^{c d}$ & $\begin{array}{r}9.96 \\
\pm \quad .53\end{array}$ & $\begin{array}{r}10.48 \\
\pm \quad .53\end{array}$ & $\begin{array}{r}9.54 \\
\pm \quad .51\end{array}$ & $\begin{array}{r}9.47 \\
\pm \quad .52\end{array}$ & $N S^{f}$ & NS & NS \\
\hline Gain, gde & $\begin{array}{r}9.84 \\
\pm \quad .49\end{array}$ & $\begin{array}{r}10.31 \\
\pm \quad .50\end{array}$ & $\begin{array}{r}9.59 \\
+\quad .47\end{array}$ & $\begin{array}{r}9.71 \\
+\quad .51\end{array}$ & NS & NS & NS \\
\hline
\end{tabular}

${ }^{a} \mathrm{LX}=$ index, LS = litter size, UT = uterine capacity, and LC = control.

${ }^{b}$ Contrast 1: IX, LS, UT, vs LC; Contrast 2: IX, LS vs UT; and Contrast 3: IX vs LS.

$\mathbf{c}_{\text {Model }}=$ replicate + criterion + replicate $\times$ criterion .

$\mathrm{d}_{\text {Gain }=\text { littering weight }- \text { mating weight. }}$

$\mathrm{e}_{\text {Model }}=$ replicate + criterion + replicate $\times$ criterion + number born as a covariate.

$\mathrm{f}_{\mathrm{NS}}=$ not statistically significant.

toward lower values. This accounts for a higher mean for pup weight than a perfectly normal distribution would have. Kurtosis values were positive; thus, there was more central tendency for pup weights than what one would expect with a perfectly normal distribution. Although not perfectly normal, the distribution can still be considered normal within the four criteria.

In a report on birth weight in pigs, the distribution of weight of littermates was normal in $67 \%$ of all litters; for the remaining litters, two discrete subpopulations of variable size could be identified (Van der Lende, 1989). Also in Van der Lende's report, the distribution of littermates' weight at birth was not an important determinant of within-litter variance in birth weight, when the comparison was made at a constant litter size.

Weights and Gain of Dams. Differences among the selection criteria occurred for mating weight and littering weight, but no differences were detected for maternal weight gain (Table 4). Contrasts IX, LS, UT vs LC and IX, LS vs UT were significant for mating weight and littering weight. The regression of maternal gain on number of pups born was significant $(.107$ $\pm .027 \mathrm{~g} / \mathrm{pup}, P<.001)$. Adjusted criterion means were less diverse, and hence there were no significant differences among them. Eisen and Durrant (1980) reported a phenotypic regression of number born on mating weight of .42 to $.45 \mathrm{pup} / \mathrm{g}$; litter size is influenced positively by a genetic effect mediated through body weight (Eisen, 1970).

Selection for uterine capacity, index, and litter size increased mating weight and littering weight, but maternal gain was the same for the different criteria. In an evaluation of Generations 22 and 23 of these same lines, differences in female mating weights at 9 wk (Clutter et al., 1994) were 9, 9, and $2 \%$ for IX, LS, and UT, respectively, compared with LC; corresponding differences at $12 \mathrm{wk}$ in this study were 14,14 , and $5 \%$. Kirby and Nielsen (1993) reported correlated selection differentials for mating weight in these lines with higher unintentional selection on mating weight in IX and LS than in UT. This is consistent with the differences observed in these data.

Number Born and Number of Males and Females. The selection criteria were significantly different for total number born and number born alive, number of males, and number of females (Table 5). The differences between the criteria where selection had been practiced and the control for total number born were IX-LC $=3.40, \mathrm{LS}-\mathrm{LC}=3.86$, and UT-LC $=1.86$. The corresponding differences for number born alive were $3.09,3.32$, and 1.90; for number of males were $1.69,2.16$, and 1.06; and for number of females were $1.77,1.64$, and .85 , respectively. Over the initial six generations of relaxed selection following the 21 generations of selection, Kirby and Nielsen (1993) found differences in number born of $3.17,4.09$, and 1.67 pups for IX-LC, LS-LC, and UT-LC, respectively. During 13 generations of relaxed selection, there has been no loss in the responses in number born that were accumulated during the selection phase. There is no evidence that favorable epistasis contributed to the response.

Contrasts IX, LS, UT vs LC and IX, LS vs UT were significant for total number born, number born alive, number of males, and number of females. The number of males were slightly larger than the number of females in every criterion. Number of pups increased without affecting the ratio of number of males and females in the litter. Rugh and Wohlfromm (1967) reported a range in variation of percentage of male offspring in mice from 51.2 to 54.5. Krackow (1990) found a positive effect of the number of embryos lost on the sex ratio (percentage of males) in wild house mice. In Berkshire and Yorkshire swine (Gray and Katanbaf, 1985), sex ratios for individual parities did not differ from one another. Sharma et al. (1991) studied sex ratio in pigs indigenous to India, and the overall ratio (percentage males) was $56.28 \pm 2.05 \%$. 
Table 5. Selection criterion least squares means for number born and significance levels of contrasts

\begin{tabular}{|c|c|c|c|c|c|c|c|}
\hline \multirow[b]{2}{*}{ Characteristic } & \multicolumn{4}{|c|}{ Criterion $^{\mathrm{a}}$ mean $\pm \mathrm{SE}$} & \multicolumn{3}{|c|}{ Significance level of contrast ${ }^{b}$} \\
\hline & $\mathrm{IX}$ & LS & UT & LC & 1 & 2 & 3 \\
\hline No. born ${ }^{c}$ & $\begin{array}{r}14.12 \\
\pm \quad .45\end{array}$ & $\begin{array}{r}14.58 \\
\pm \quad .45\end{array}$ & $\begin{array}{r}12.58 \\
\pm \quad .44\end{array}$ & $\begin{array}{r}10.72 \\
\pm \quad .44\end{array}$ & .001 & .02 & $\mathrm{NS}^{\mathrm{d}}$ \\
\hline No. born alive ${ }^{c}$ & $\begin{array}{r}13.38 \\
\pm \quad .39\end{array}$ & $\begin{array}{r}13.61 \\
\pm \quad .39\end{array}$ & $\begin{array}{r}12.19 \\
\pm \quad .38\end{array}$ & $\begin{array}{r}10.29 \\
+\quad .39\end{array}$ & .001 & .04 & NS \\
\hline No. of males ${ }^{c}$ & $\begin{array}{r}7.20 \\
\pm \quad .26\end{array}$ & $\begin{array}{r}7.67 \\
+\quad .25\end{array}$ & $\begin{array}{r}6.57 \\
+\quad .24\end{array}$ & $\begin{array}{r}5.51 \\
+\quad .24\end{array}$ & .001 & .03 & NS \\
\hline No. of females & $\begin{array}{r}6.90 \\
+\quad .26\end{array}$ & $\begin{array}{r}6.77 \\
+\quad .26\end{array}$ & $\begin{array}{r}5.98 \\
\pm \quad .25\end{array}$ & $\begin{array}{r}5.13 \\
\pm \quad .26\end{array}$ & .003 & .04 & NS \\
\hline
\end{tabular}

a IX $=$ index, LS = litter size, UT = uterine capacity, and LC = control.

bContrast 1: IX, LS, UT vs LC; Contrast 2: IX, LS vs UT; and Contrast 3: IX vs LS.

${ }^{\mathrm{c}}$ Model $=$ replicate + criterion + replicate $\times$ criterion .

$\mathrm{d}_{\mathrm{NS}}=$ not statistically significant.

\section{Implications}

Selection to increase litter size in mice did not affect pup birth weight, but maternal weight increased. Variability in pup birth weight was only slightly affected. If these results hold for other species with relatively large litters (e.g., swine), selection for litter size in these species could be practiced without changing weights and variability of young in an unfavorable direction.

\section{Literature Cited}

Bakker, H., J. H. Wallinga, and R. D. Politiek. 1978. Reproduction and body weight of mice after long-term selection for large litter size. J. Anim. Sci. 46:1572.

Clutter, A. C., Y. L. Kochera Kirby, and M. K. Nielsen. 1994. Uterine capacity and ovulation rate in mice selected 21 generations on alternative criteria to increase litter size. J. Anim. Sci. 72:577.

Clutter, A. C., M. K. Nielsen, and R. K. Johnson. 1990. Alternative methods of selection for litter size in mice: I. Characterization of base population and development of methods. J. Anim. Sci. 68:3536.

Eisen, E. J. 1970. Maternal effects on litter size in mice. Can. J. Genet. Cytol. 12:209.
Eisen, E. J., and B. S. Durrant. 1980. Genetic and maternal environmental factors influencing litter size and reproductive efficiency in mice. J. Anim. Sci. 50:428.

Gion, J. M., A. C. Clutter, and M. K. Nielsen. 1990. Alternative methods of selection for litter size in mice: II. Response to thirteen generations of selection. J. Anim. Sci. 68:3543.

Gray, E., and M. N. Katanbaf. 1985. Sex ratio and distribution of sexes in swine. J. Hered. 76:36.

Kirby, Y. L., and M. K. Nielsen. 1993. Alternative methods of selection for litter size in Mice: III. Response to 21 generations of selection. J. Anim. Sci. 71:571.

Krackow, S. 1990. Sex-specific embryonic mortality during concurrent pregnancy and lactation in house mice. J. Exp. Zool. 256: 106.

Rugh, R., and M. Wohlfromm. 1967. The reproductive performance of the laboratory mouse: Maternal age, litter size and sex ratios. Proc. Soc. Exp. Biol. Med. 126:685.

SAS. 1992. SAS/STAT ${ }^{\circledR}$ User's Guide: Statistics (Version 6, 4th Ed.). SAS Inst. Inc., Cary, NC.

Shapiro, S. S., and M. B. Wilk. 1965. An analysis of variance test for normality (complete samples). Biometrika 52:591.

Sharma, G. C., R. R. Mishra, and G. S. Bisht. 1991. Studies on sex ration in indigenous pigs. Indian J. Anim. Res. 25(1):53.

Snedecor, D. W., and W. G. Cochran. 1967. Statistical Methods. Iowa State University Press, Ames.

Van der Lende, T. 1989. Impact of early pregnancy on prenatal development in the pig. Proefschrift Wageningen, The Netherlands. 